Dept. of Virology, Faculty of Veterinary Medicine,

Banha University, 13736 Moshtoher, Egypt.

\title{
VIROLOGIC, SEROLOGIC AND PATHOLOGIC STUDIES INTO BORDER DISEASE VIRUS (BDV) INFECTION IN A GOAT HERD IN SAUDIA ARABIA (With 6 Figures)
}

\section{By \\ S.S.A. SHARAWI; M.R. YOUSEF ${ }^{*}$; KH.Z. DOKHAN ${ }^{* *}$ and A.N. AL-HOFUFY ${ }^{* *}$}

*FMD Department, Veterinary Serum and Vaccine Research Institute, Abbasia,

Cairo, Egypt.

**Dept. of Pathology, Animal Reproduction Research Institute, AL-Harm, Giza, Egypt.

***Central Veterinary Diagnostic Lab, Ministry of Agriculture, Riyadh, 11195 , KSA.

(Received at 24/7/2010)

دراسات فيروسية وسيرولوجية ومرضية للإصابة بمرض الحدود الفيروسي في بي

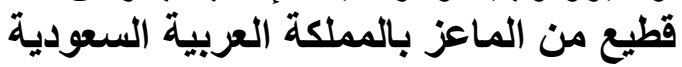

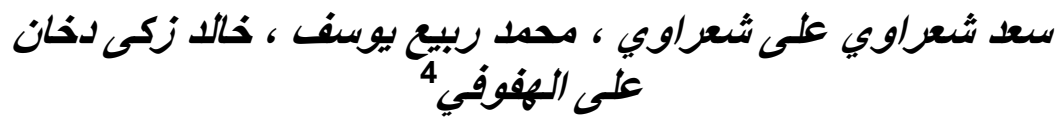

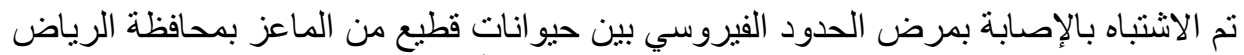

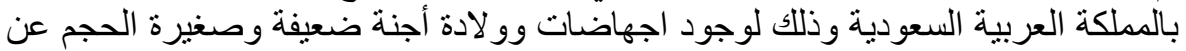

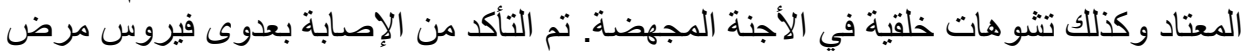

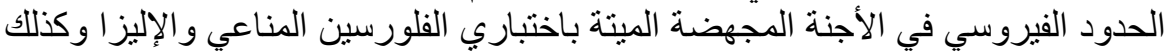

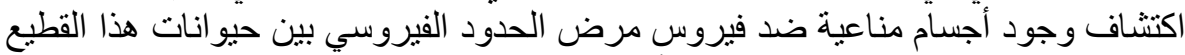

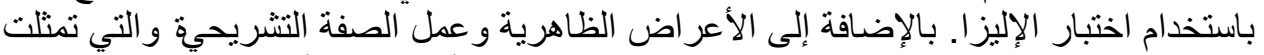

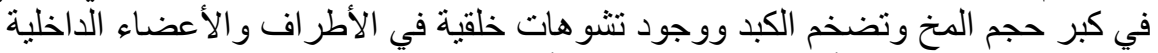

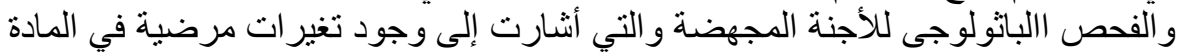

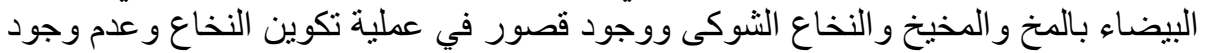

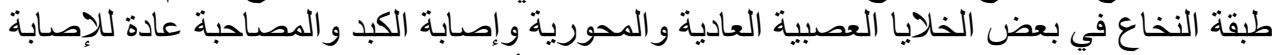

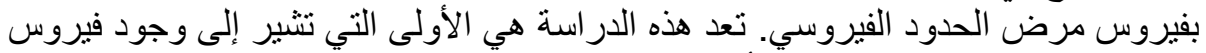

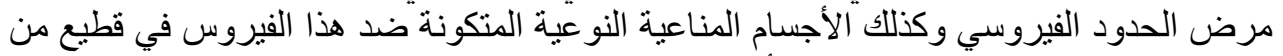

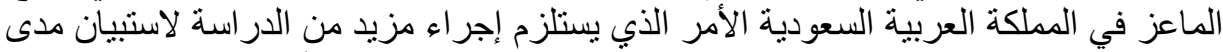

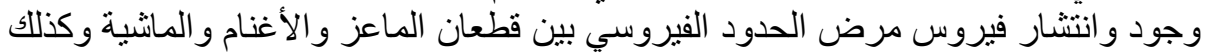
محاولة الوقوف على نوع وطبيعة عتره هذا الفيروس. 


\section{SUMMARY}

In this study, border disease virus (BDV) infection was suspected in a goat herd in Riyadh province, KSA. The outbreak was unusual in that the typical clinical signs of border disease, i.e., tremor and/or fleece changes were not present; manifestations of disease were restricted to abortion and the birth of small weak kids. The diagnosis was confirmed by virus detection from dead-born fetuses, seroprevalence and pathology. Impression smears from internal organs of aborted feti with suspected border disease (BD) were stained with the direct fluorescent antibody technique and examined by fluorescent microscopy, as well as prepared samples were assessed by antigen ELISA, where the two assays indicated the existence of BDV antigen. In addition; the serological investigation performed to determine the prevalence of (BDV) antibodies using ELISA revealed concurrent infection of BDV among this goat herd. Histopathological changes were confined to the brain, spinal cord and liver. Lesions were especially pronounced in the white matter of the cerebrum and the cerebellum. This is the first study that shows the presence of BDV and serologically positive animals to BDV in KSA. Further studies are needed in order to determine the prevalence of the disease in the other goat and sheep populations and the strains of the virus may be present in KSA.

Key words: Border disease virus, Goat, Pathology.

\section{INTRODUCTION}

Border disease virus (BDV) is a Pestivirus within the family Flaviviridae and is closely related to classical swine fever virus (CSFV) and bovine viral diarrhoea virus (BVDV). Taxonomy of Pestivirus is quite problematic at present; there are four recognised species, namely: CSFV, BVDV types 1 and 2 and BDV (Horzinek, 1991 and Theil, et al., 2005). Border disease (BD) was first described and reported as a clinicopathological entity in sheep in Great Britain in 1959 (Hughes and Kershaw, 1959). The condition was endemic in the border countries between England and Wales, which explains the name border disease. The virion of $\mathrm{BD}$, although mainly spherical is pleomorphic in nature, has a diameter of about $45-50 \mathrm{~nm}$ and has a tightly adherent envelope. The genome is made up of a single molecule of linear positive-sense singlestranded ribonucleic acid (RNA) molecule. The size of the pestivirus genomic RNA was estimated by gel electrophoresis to be 12-13 kilo bases (kb) in size (Collett, 1992 and Becher et al., 2003). The genome encodes a single polyprotein that is proteolytically processed during virus replication 
to produce a variety of viral structural and non-structural proteins (Murphy et al., 1999). The sensitive and reliable diagnosis of BVD infections is becoming increasingly important. Direct immunofluorescence and other immunohistochemical techniques on frozen tissue sections, as well as antigen-detecting ELISA and conventional and real-time RT-PCR are also valuable methods for identifying $\mathrm{BDV}$-infected animals, to detect antibodies against the virus in the latter case; neutralisation tests and enzyme-linked immunosorbent assays are mostly applied (OIE, 2008). Few reports described BD infection and histopathological lesions in naturally or experimentally infected goat and sheep (Krametter-Froetscher et al., 2009). The post mortem examination and histopathological changes in aborted feti are of great importance in diagnosis of caprine border disease (Pratelli et al., 1999 and Liebler-Tenorio et al., 2000). To date, and to our knowledge, there is no study that has looked at the pestivirus infection among animal populations in KSA. This study may be a preliminary model understands the BDV infection within a goat herds in KSA.

\section{MATERIALS and METHODS}

\section{Case presentation and samples:}

In January 2010, goat herd located in Riyadh Province was housed in the same stable with cattle and sheep, but in separate ranges. At this time the goat breeding stock of the farm consisted of 20 goat ewes. During winter time; the first abortion was recognized in an ewe, until February abortion was documented in further seven of the ewes. The most obvious features of the aborted feti were congenital anomalies. The local veterinarian sent materials from a further abortion (two feti and placentas) as well as blood samples (without anticoagulant) from fifty ewes, to the Central Veterinary Diagnostic Lab. (CVDL), Ministry of Agriculture, Riyadh, KSA. Clinically signs aside from abortion were not recognized in the neighboring sheep and cattle flocks described.

\section{Fluorescent antibody technique (FAT):}

In the guide of Burleson et al. (1997); an impression smears from internal organs of aborted fetus were dried at $37^{\circ} \mathrm{C}$, fixed at aquas acetone ethanol (1:1) over night at $4{ }^{\circ} \mathrm{C}$, then washed triple with PBS(SIGMA). Porcine anti- BVDV polyclonal antiserum conjugated to fluorescein isothiocyanate (VMRD, Inc., Pullman.USA. Catalog no. 210-60-BVD. Lot No. P060808BVDP) was added (50 $\mu \mathrm{l} /$ slide). All examined slides were incubated at $37^{\circ} \mathrm{C}$ for one hour, followed by triple washing with PBS containing $0.1 \%$ bovine albumin (BD-BBL, Ireland), mounted in glycerol saline and examined under fluorescent microscope. 


\section{Enzyme linked immunosorbant assay (ELISA):}

An indirect commercial antigen ELISA kit (SYNBIOTICS, France) was used for detection of BVD/BD antigen (P80/125 non structural protein), which possesses an epitope common to all cytopathogenic and non-cytopathogenic strains of BVD/BD viruses. The prepared samples (fetus organs) as well as the test were performed following manufacturer's instruction. ELISA kit for detection of specific antibodies to the P80 protein of the viruses of BVD/BD (Institute POURQUIER, BVD/MD/BD P80 antibody Screening- Version P00645/02-03/08/2005) was used. The assay was applied for examined serum samples according to the manufacturer's instruction to detect and differentiate the presence of antibodies to either BVDV or BDV.

\section{Histopathological study:}

Tissue samples were taken from internal organs of aborted feti and were fixed in $10 \%$ neutral buffered formalin. The fixed specimens were washed, dehydrated and embedded in paraffin wax. The tissues were sectioned at 4-5 Mm thickness and stained with haematoxylin and eosin $(\mathrm{H}$ and E) as routine work for histopathological examination according to Bancroft and Stevenes (1996).

\section{RESULTS}

The results obtained in this study revealed that, the affected aborted kids are smaller than normal, showing poor live weight gains. All of the examined feti have central nervous system (CNS) lesions ranging from mild to moderate in severity. There may be hydroencephaly; presence of cavities in the brain (Fig.1); and liver enlargement and congenital deformities of the head, limbs and internal organs (Fig.2) were revealed at the post-mortem (PM) examination. In young kids observed fluorescences as well as positive antigen ELISA were recorded in almost every organs, demonstrating a generalised infection with BDV, while seven of fifty (14\%) of the examined sera showed positive results for BDV antibodies presentation. Histopathological changes were confined to the brain, spinal cord and liver. Lesions were especially pronounced in the white matter of the cerebrum and the cerebellum. Significant histological changes were restricted largely to hypercellular foci and mild perivascular cell infiltration in the white matter of CNS, in addition to demylination of axons and nerve fibers (Fig.3, 4). In most of the kids studied there appeared to be secondary degeneration of myelin as well as a primary hypomyelinogenesis. The blood vessels of brain meninges appeared dilated and engorged with blood (Fig.5). Liver lesions revealing necrobiotic changes and vacuolar degeneration in the hepatocytes (Fig.6). 


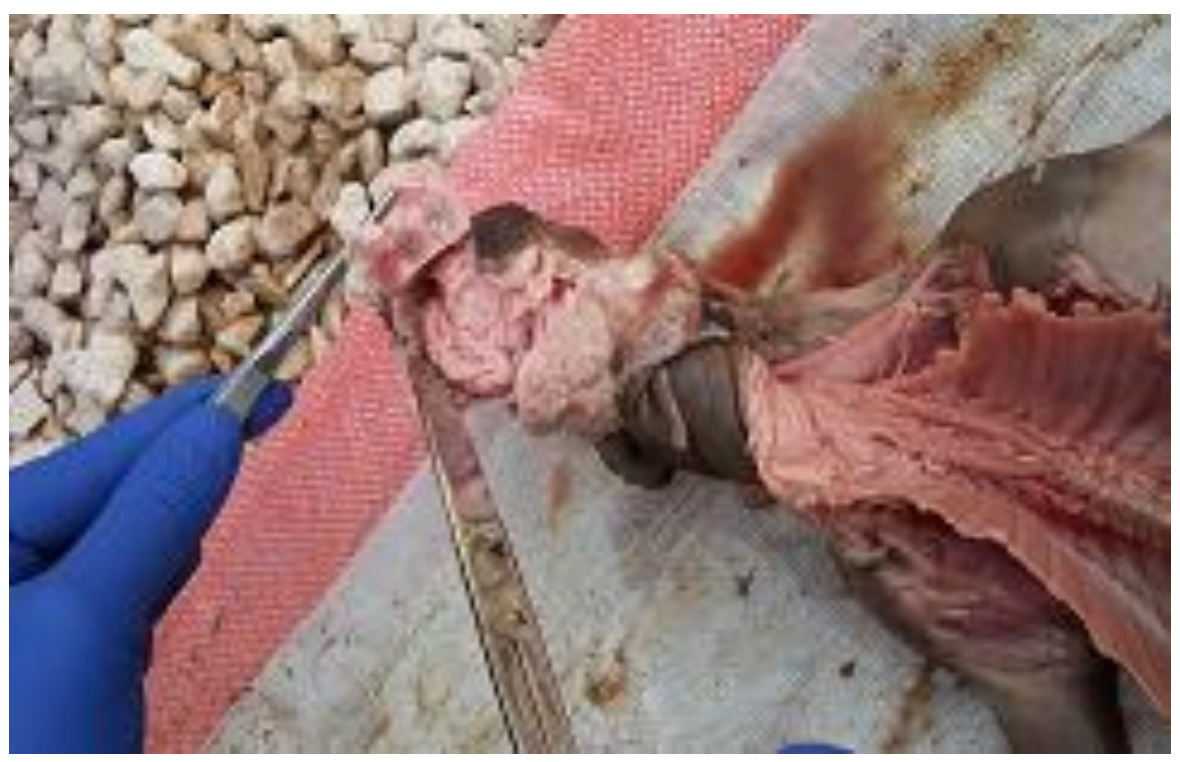

Fig. 1: A case of goat kid revealed enlargement of the brain with cavitation.

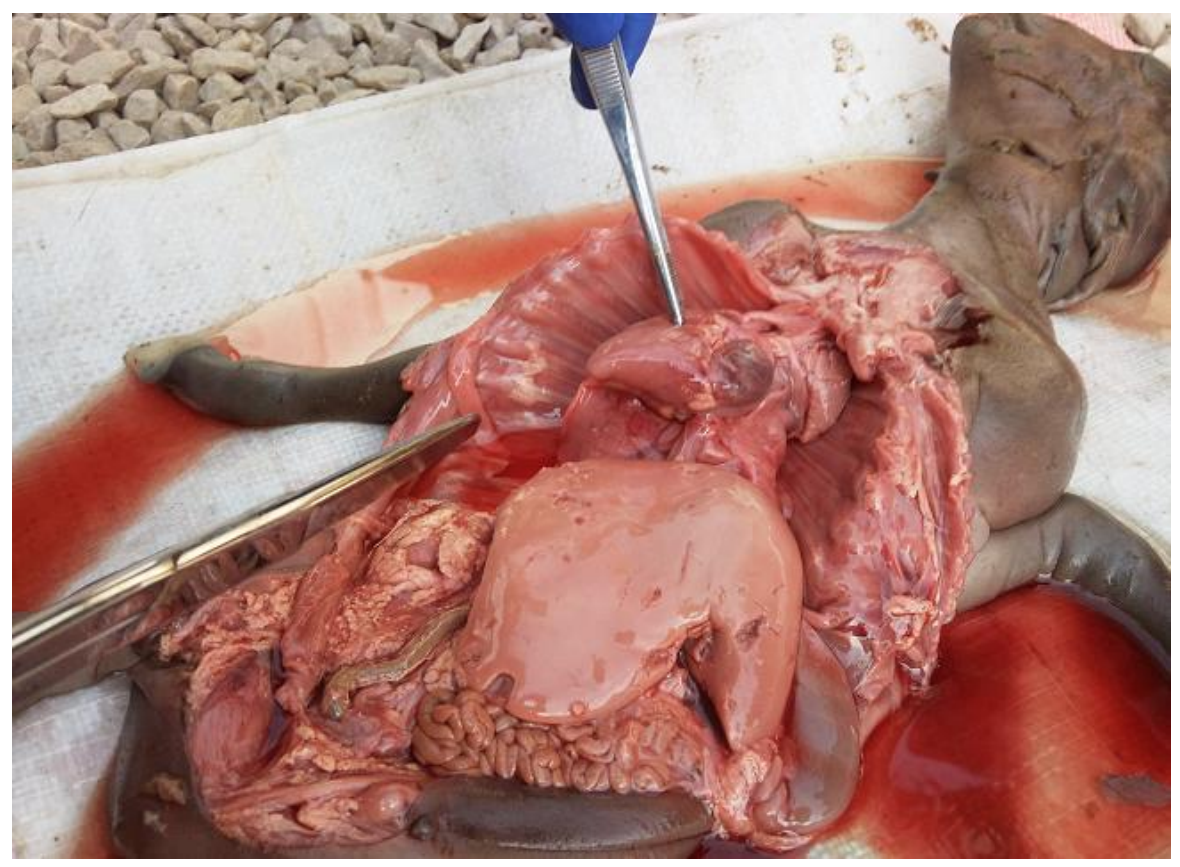

Fig. 2: A case of goat kid revealed liver enlargement and congenital deformities of the head fore limbs and internal organs. 


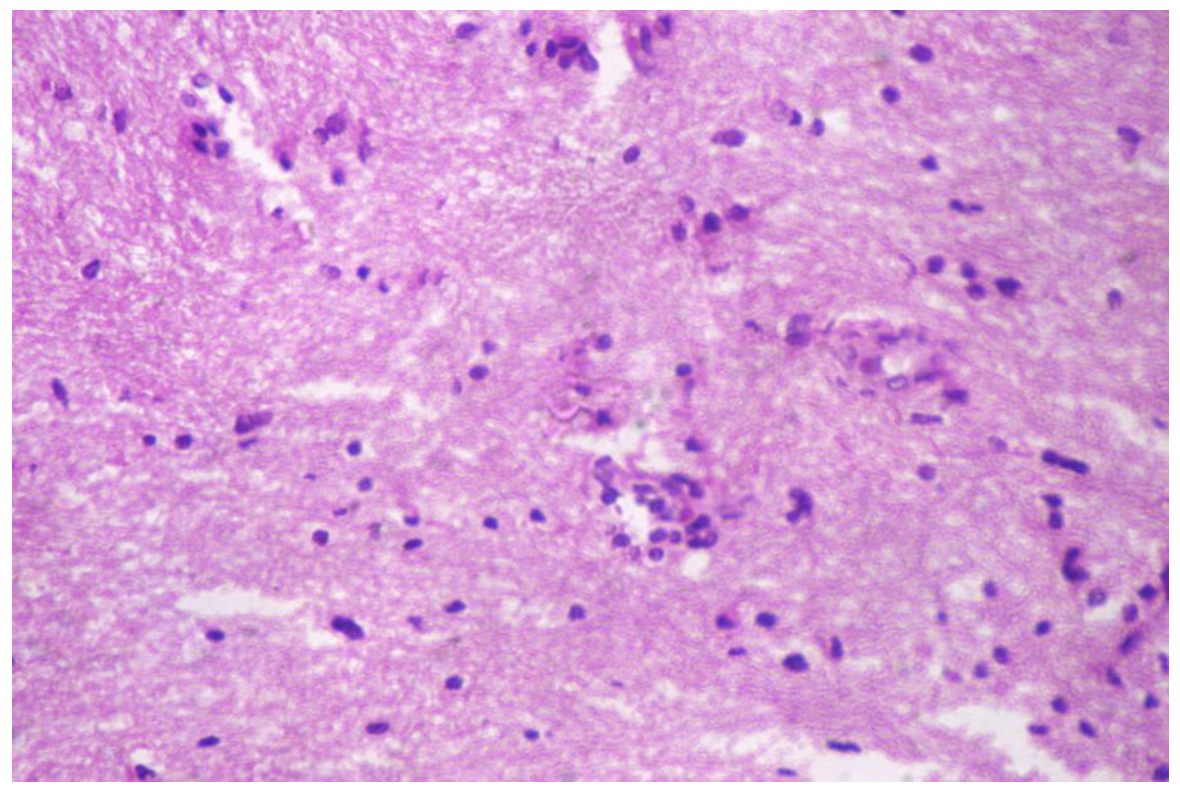

Fig. 3: Brain of goat kid showing focal gliosis in the cerebrum. ((H\&E; X400).

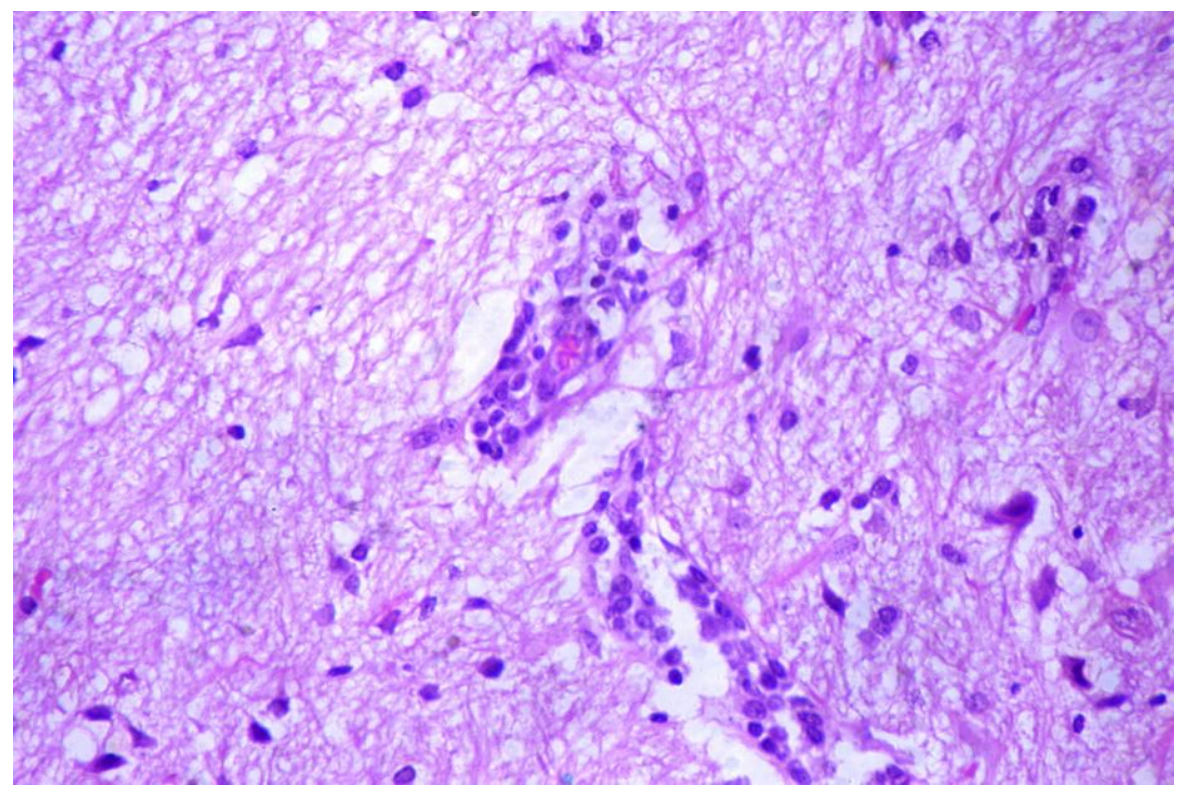

Fig. 4: Brain goat kid showing demylination of axons or nerve fibers together with perivascular cuffing. (H\&E; X400). 


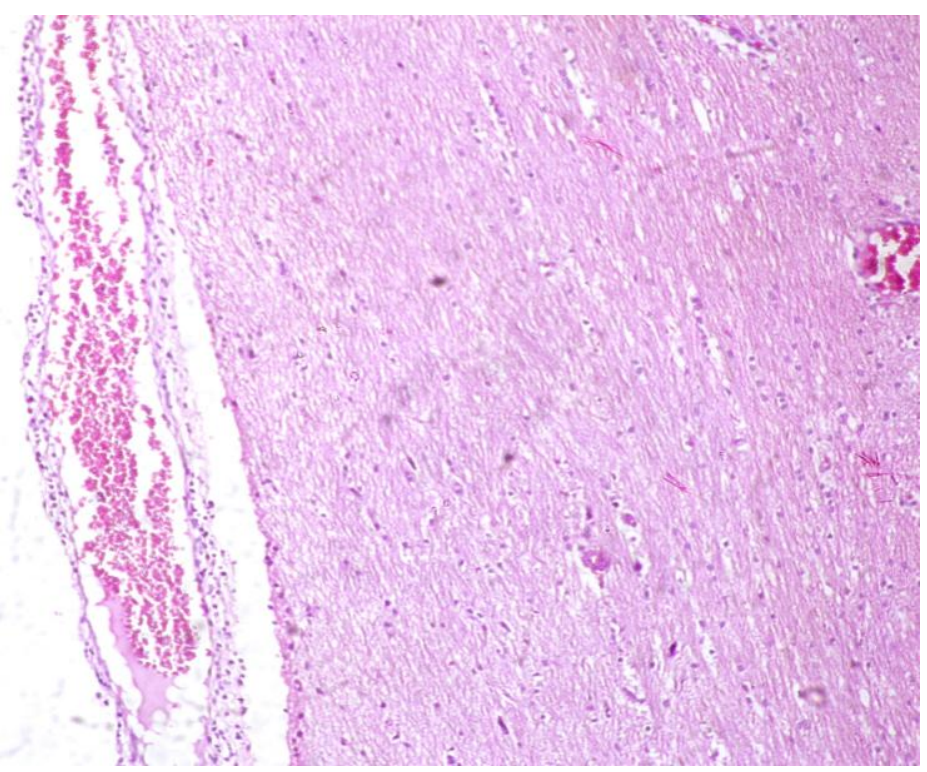

Fig. 5: Brain of goat kid showing congestion of meningeal blood vessels. (H\&E; X100).

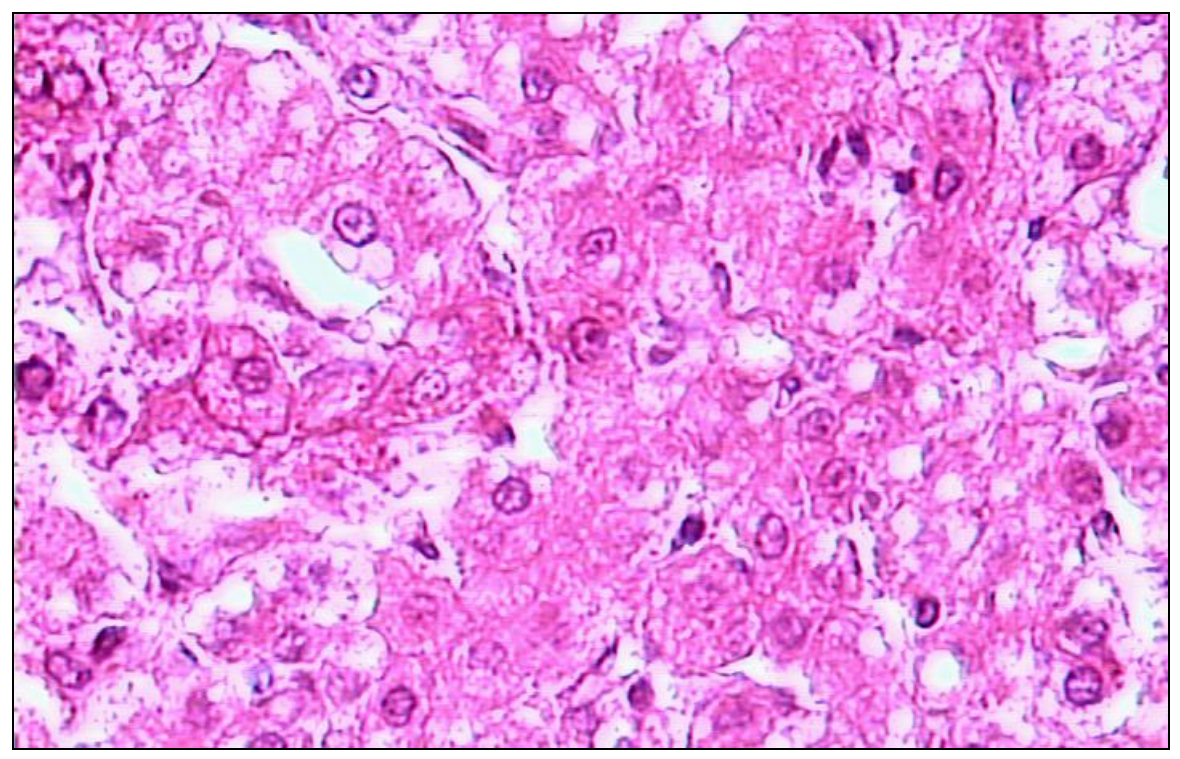

Fig. 6: Liver of goat kid showing necrobiotic changes and vacuolar degeneration of hepatocytes (H\&E; X400). 


\section{DISCUSSION}

A diagnosis of BD in sheep was made on the basis of the clinical findings in affected lambs, necropsy results and detection of viral antigen (Campbell et al., 1995). Few reports described clinical and PM lesions of BD in naturally or experimentally infected goats (Løken, 2000 and Krametter-Froetscher et al., 2009). Many of the signs and macroscopic lesions associated with $\mathrm{BD}$, such as abortion, stillbirth and birth of small weak kids, were evident in our current study.

The clinical signs and PM examination as a consequence of BD infection recorded in this study; have never been reported in KSA, although previous epidemiological studies had shown that BDV outbreak is common in most sheep herds causing an important congenital disease and is probably distributed worldwide (Nettleton, 1990). Intrauterine infections during early pregnancy can cause fetal death and abortions. Alternatively, intrauterine infections during the first half of gestation can result in lambs which show tremor, ataxia, hairy fleece, brain malformations and poor growth. The affected lambs, termed hairy shakers, are persistently infected and play an important role in BDV transmission (Nettleton, 1990 and Terpstra, 1981). In addition, a syndrome similar to mucosal disease of cattle has been described for sheep infected with ruminant pestiviruses (Barlow et al., 1983 and Nettleton et al., 1992).

Virological and serological examinations might give an ultimate diagnosis in a suspect case of $\mathrm{BD}$, and are obviously necessary to confirm a clinical and/or pathological diagnosis (Nettleton and Entrican, 1992). The virological investigations for pestivirus detection in this work were performed using FAT and antigen ELISA test, where; the antigen was recorded in almost every organs, demonstrating a generalized BDV infection, this may be attributed to the fact that, a tentative pathogenesis of BD includes super-infection with a cytopathogenetic strain which is homologous to the primary persistent non-cytopathogenic virus (Nettleton et al., 1992). Direct FAT was used for identifying BDV-infected animals (OIE, 2008), while the indirect ELISA is a standard method to detect pestivirus in several diagnostic laboratories and is used in the BVDV control programme (Terpstra, 1987; Lindberg, 2005 and Kampa et al., 2007).

Examination for BDV antibodies can be performed by different methods, although virus neutralization tests are most sensitive and accurate for quantitative evaluation. Serological testing for pestivirus infections, like virological examination, is nowadays largely based on different modifications of the ELISA assay (Løken, 2000). The examined sera in the 
present work showed positive results for BDV antibodies presentation. This is the first report of antibodies to pestiviruses in goat in KSA. Although the number of tested animals in this study was small; the seroprevalence of $14 \%$ (seven of fifty) in goat sera is contrast to the $3 \%$ prevalence measured in Bavaria (Schmitt and Wittkowski, 1999) and the $5 \%$ prevalence documented from Denmark (Nielsen et al., 2000).

The border disease affected kids are smaller than normal, develop very slowly, and sudden deaths may occur. These factors contribute considerably to the economic cost of the disease. Few reports describe histopathological lesions in naturally or experimentally infected goat and sheep (Krametter-Froetscher et al., 2009). The lesions of affected goat kids recorded in this work were especially pronounced in the white matter of the cerebrum and the cerebellum. Significant histological changes were restricted largely to hypercellular foci and perivascular cell infiltration in the white matter of CNS; in addition to demylination of axons and nerve fibers. In most kids studied there appeared to be secondary degeneration of myelin as well as a primary hypomyelinogenesis. These lesions were similar to naturally and experimental studies in ovine (Vantsis, 1976; Clarke and Osburn, 1978; Wilsmore and Roeder, 1984 and Oguzoglu et al., 2009). The descriptions agree with those reported in goats and cattle (Løken, 1987; Pratelli et al., 1999 and Liebler-Tenorio et al., 2000). Necrobiotic changes and vacuolar degeneration in the hepatocytes were observed. These results indicate that extensive infection of CNS cells with their subsequent destruction or functional alteration may be a critical part of the pathogenesis of the BD.

In the present study, the possibility of goat infection remains in that either the BDV was transmitted from neighboring sheep or cattle herds, or that the virus was present in persist infected animal among examined goat flock. It is not possible to answer this question in the present study, so further studies are needed in order to determine the prevalence of the disease in the other goat, sheep and cattle populations and the strains of the virus present in KSA.

\section{ACKNOWLEDGEMENTS}

We would like to thank Dr. Ali EL-Essa, Manger Director of Central Veterinary Diagnostic Lab, Ministry of Agriculture, Riyadh, KSA, for his fruitful collaboration. 


\section{REFERENCES}

Bancroft, J.D. and Stevens, A. (1990): Theory and Practice of Histopathological Techniques. Third edition, New York.

Barlow, R.M.; Gardiner, A.C. and Nettleton, P.F. (1983): The pathology of a spontaneous and experimental mucosal disease in sheep recovered from clinical border disease. J. Comp. Pathol. 93: 451-461.

Becher, P.; Avalos-Ramirez, R.; Orlich, M.; Rosales, S.C.; König, M. and Schweizer, M. (2003): Genetic and antigenic characterization of novel pestivirus genotypes: Implications for classification, Virol. 311: 96-104.

Burleson, F.G.; Chamber, T.M. and Wiedbrank, D.L. (1997): Virlogy:A laboratory Manual.Academic Press, INC,Harcourt Brace Jovanovich, publisher.

Campbell, J.R.; Radostits, O.M.; John T.W. and Eugene, D.J. (1995): An outbreak of Border disease in a sheep flock. Can. Vet. J., 36: 307-309.

Clarke, G.I. and Osburn, B.I. (1978): Transmissible congenital demyelinating encephalopathy of lambs. Vet. Path. 15: 68-82.

Collett, M.S. (1992): Molecular genetics of pestivirus. Comp. Immunol. Microbiol. Infect. Dis. 15, 145-54.

Horzinek, M.C. (1991): Pestiviruses, Taxonomic perspectives. Archives of Virology. Supplementum 3: 1-5.

Hughes, L.E. and Kershaw, G.F. (1959): "B" or Border disease. An undescribed disease of sheep. Vet. Rec., 71: 313-317.

Kampa, J.; Karl Ståhl; Lena HM Renström and Stefan Alenius (2007): Evaluation of a commercial Erns-capture ELISA for detection of BVDV in routine diagnostic cattle serum samples. Acta Vet. Scandinavica, 49: 1-7.

Krametter-Froetscher, R.; Duenser, M.; Preyler, B.; Theiner, A.; Benetka, V.; Moestl, K. and Baumgartner, W. (2009): Pestivirus infection in sheep and goats in West Austria. Vet. J. (under publish) http://www.ncbi.nlm.nih.gov/pubmed/20042353.

Liebler-Tenorio, E.M.; Lanwehr, A.; Greiser-Wilke, I.; Loehr, B.I. and Pohlenz, J. (2000): "Comparative investigations of tissue alterations and distribution of BVD-viral antigen in cattle with early onset versus late onset mucosal disease". Vet. Microbiol., 77, (1-2) 163-174.

Lindberg, A. (2005): Contrywide eradication of BVDV- How can it be done?: Wellington (Ed.), New Zealand., 53-62. 
Løken, T. (1987): Experimentally-induced border disease in goats. J. Comparative Pathol., 97 (1) 85-89.

Løken, T. (2000): Border Disease in Goats. In: Recent Advances in Goat Diseases, Tempesta M. (Ed.) Publisher: International Veterinary Information Service (www.ivis.org).

Murphy, F.A.; Gibbs, E.P.J.; Horzinek, M.C. and Studdert, M.J. (1999): Classification and nomenclature of viruses. In: Veterinary Virology, 3rd Edn, Academic press, New York.

Nettleton, P.F. (1990): Pestivirus infections in ruminants other than cattle. Rev. Sci. Tech. Off. Int. Epizoot. 9:131-150.

Nettleton, P.F. and Entrican, G. (1992): The diagnosis of ruminant pestivirus infections. In: Proceedings of the 2nd Symposium on Pestiviruses 1992; 185-191.

Nettleton, P.F.; Gilmour, J.S.; Herring, J.A. and Sinclair, J.A. (1992): The production and survival of lambs persistently infected with border disease virus. Comp. Immunol. Microbiol. Infect. Dis. 15: 179-188..

Nielsen, S.S.; Roensholt, L. and Bitsch, V. (2000): Bovine virus diarrhea virus in free-living deer from Denmark. Journal of Wildlife Diseases 36: 584-587.

Office International des Epizooties (OIE) (2008): BORDER DISEASE. OIE Terrestrial Manual, Chapter 2.7.1, 963-973.

Oguzoglu, T.C.; Tan, M.T.; Toplu, N.; Demi, A.B.; Bilge-Dagalp, S.; Karaoglu, T.; Ozkul, A.; Alkan', F.; Burgu, I.; Haas, L. and Greiser-Wilke, I. (2009): Border disease virus (BDV) infections of small ruminants in Turkey: A new BDV subgroup? Veterinary Microbiology Volume 135, Issues 3-4, 30 March 2009, Pages 374-379.

Pratelli, A.; Bollo, E.; Martella, V.; Guarda, F.; Chiocco, D. and Buonavoglia, C. (1999): Pestivirus infection in small ruminants: virological and histopathological findings. New Microbiol.; 22(4): 351-6.

Schmitt, D. and Wittkowski, G. (1999): Untersuchungen zur Verbreitung von BVD-Virusinfektion bei Schalenwild in Bayern [Study on the prevalence of BVD infection in free living cervids, chamois and wild boar in Bavaria]. Tiera"rztliche Umschau 54: 284-288.

Terpstra, C. (1981): Border disease: Virus persistence, antibody response and transmission studies. Res. Vet. Sci. 30: 185-191.

Terpstra, C. (1987): Detection of Border disease antigen in tissues of affected sheep and in cell cultures by immunoflorescence. Res. Vet. Sci., 25: 350-355. 
Theil, H.J.; Collett, M.S.; Gould, E.A.; Heinz, F.X.; Houghton, M.; Meyers, G.; Purcell, R.H. and Rice, C.M. (2005): Flaviviridae. In: Virus Taxonomy. Eighth report of the International Committee on Taxonomy of Viruses, Fauquet C.M., Mayo M.A., Maniloff J., Desselberger U. \& Ball L.A., eds. Elsevier Academic Press, 981-998.

Vantsis, J.T.; Barlow, R.M.; Fraser, J.; Rennie, J.C. and Mould, D.L. (1976): "Experiments in Border disease: VIII propagation and properties of a cytopathic virus" Journal of Comparative Pathology Volume 86, Issue 1, Pages 111-120.

Wilsmore, A.J. and Roeder, P.L. (1984): "BORDER DISEASE IN SYRIA" Trop. Anita. Hlth Prod., 16: 225-226. 